\title{
Perancangan Sistem Informasi Laporan Pertanggungjawaban Bendahara Pengeluaran pada Kantor Kecamatan Oba Selatan
}

\author{
Darman Umagapi ${ }^{1}$, Syahril Hasan ${ }^{2}$ \\ Program Studi Manajemen Informatika ${ }^{1}$, Program Studi Komputerisasi Akuntasi ${ }^{2}$ \\ Politeknik Sains dan Teknologi Wiratama Maluku Utara \\ umagapie01@yahoo.com
}

\begin{abstract}
Abstrak
Perkembangan teknologi komputer dibuktikan dengan mekanisme kerja yang panjang lebih efektif dan efisien. Baik dalam sumber daya hardware (perangkat keras), software (perangkat lunak) dan brainware (manusia). Dari hasil observasi yaitu masalah yang dihadapi oleh petugas Kantor kecamatan tersebut adalah pada penyusunan laporan pertanggungjawabnya. Penelitian ini bertujuan Untuk membuat suatu sistem informasi penyusunan Laporan Pertanggungjawaban Bendahara Pengeluaran di Kecamatan Oba Selatan dengan menggunakan bahasa pemograman Visual Studio dan Ms. Access sebgagai databasenya. Dalam penelitian ini, penulis menerapkan beberapa metode diantaranya analisis, perancangan dan implementasi dari suatu sistem tersebut. Hasil penelitian ini adalah untuk Memberi kemudahan dalam memasukan data belajan barang, mengolah data gaji pegawai, serta pembuatan laporan pengeluaran bendahara pengeluaran berdasarkan periode.
\end{abstract}

\section{Kata Kunci: Laporan, Pertanggungjawaban, Bendahara, Pengeluaran}

\begin{abstract}
The development of computer technology is proven by a long working mechanism that is more effective and efficient. Both in hardware (hardware), software (software) and brain-ware (human) resources. From the observation results, the problems faced by the sub-district office officers are in the preparation of their accountability reports. This study aims to create an information system for preparing the Treasurer Expenditure Accountability Report in South Oba District, using Visual Studio programming language and Ms. Access as the database. In this study, the authors applied several methods including analysis, design, and implementation of a system. The results of this study are to provide convenience in entering data learning items, processing employee salary data, and making treasury expenditure reports based on period.
\end{abstract}

Keyword: Reports, Responsibility, Treasurer, Expenditures

\section{PENDAHULUAN}

Pelaksanaan Anggaran merupakan bagian dari siklus Anggaran Pendapatan dan Belanja Negara (APBN). Salah satu indikator penting untuk mengetahui kinerja APBN adalah dengan mengukur tingkat penyerapan anggaran dalam pelaksanaan anggaran. Besaran bagi anggaran yang dapat direalisasikan dapat mencerminkan berjalannya fungsi-fungsi pemerintahan antara lain mendorong pertumbuhan ekonomi, distribusi yang semakin merata dan stabilitas perekonomian yang makin terjaga. Mengingat pentingnya penyerapan anggaran dalam menggerakkan perekonomian bangsa, maka perlu dilakukan berbagai langkah untuk mendorong percepatan penyerapan anggaran.

Direktorat Jenderal Perbendaharaan selaku Kuasa Bendahara Umum Negara bertugas untuk mendorong percepatan realisasi penyerapan anggaran pada Kementerian Negara/Lembaga dalam mencapai sasaran program dan kegiatan yang menjadi tanggung jawab. Sebagai 
identifikasi awal, rendahnya penyerapan anggaran mengindikasikan adanya permasalahan baik dari sisi teknis maupun regulasi

Peneliti melakukan beberapa observasi terhadap penyusunan atau pengimputan data yang berjalan, Penyusunan Laporan Pertanggungjawaban Bendahara Pengeluaran di Kecamatan Oba Selatan ini dan hasil observasi yaitu masalah yang dihadapi oleh petugas Kantor kecamatan tersebut adalah pada penyusunan laporan pertanggungjawabnya.

Perkembangan Teknologi Informsi semakin mempermudah pekerjaan seseorang yang sebelumnya secara manual, berkat dukungan Tekniolgi komputer hal ini dibuktikan dengan mekanisme kerja yang panjang menjadi lebih efektif dan efisien. Baik dalam sumber daya hardware (perangkat keras), software (perangkat lunak) dan brainware (manusia).

Berdasarkan latar belakang tersebut maka peneliti mencoba untuk membuat Laporan Pertanggung Jawaban Bendahara Pengeluaran dengan menggunakan Visual Studio. "Laporan Pertanggungjawaban Bendahara Pengeluaran pada Kantor Kecamatan Oba Selatan”.

\section{Rumusan Masalah}

Berdasarkan latar belakang tersebut diatas,maka peneliti dapat merumuskan masalah yaitu: "Bagaimana membuat Laporan Pertanggungjawaban Bendahara Pengeluaran di Kecamatan Oba Selatan"?

\section{Tujuan Penelitian}

Adapun tujuan penelitian ini adalah Untuk merancang sistem informasi penyusunan Laporan Pertanggungjawaban Bendahara Pengeluaran di Kecamatan Oba Selatan.

\section{Manfaat Penelitian}

1. Diharapkan penelitian ini mempermudah dalam penyusunan laporan Pertanggung Jawaban bendahara pengeluaran

2. Diharapkan memberikan manfaat bagi peneliti lain sebagai bahan acuan yang sesuai dengan penelitian ini.

3. Dapat dijadikan sebagai bahan referensi bagi peneliti lain pada masa yang akan datang.

\section{Tinjauan Pustaka}

Penelitian yang dilakukan oleh Elsya Vera Indraswari , Noor Latifah (2014) yang berjudul Sistem Informasi Surat Pertanggung Jawaban (SPJ) Pembantu Bendahara Pengeluaran Pada Badan Kepegawaian Daerah Kudus, Tujuan Penelitian merancang sebuah sistem baru berbasis komputer (terprogram) yang difungsikan sebagai media pengolahan data, baik data-data pegawai maupun data-data transaksidan kesulitan-kesulitan yang selama ini terjadi dapat di tangani secara efektif dan efesien. Kesimpulan beberapa kesimpulan dari penelitian ini diantara lain adalah dalam penyusunan data master sudah dapat terdata dengan baik Penilitian ini dilaksanakan di Perusahaan Dwi Jaya Otomotif - Sampit dengan jenis data yang di ambil dari cara observasi, wawancara dan dokumentasi. pendekatan analisis yang digunakan yaitu pendekatan top down, dan analisis sistem dideskripsikan sebagai berikut: laporan pertanggung jawaban bendahara pengeluaran. Hasil perbandingan Pada penelitian ini Model analisis sistem yang digunkan adalah analisys driven model terstruktur dan pengembangan sistem menggunakan model waterfall

Penelitian yang dilakukan oleh Dwi Rizky Rahmatiah (2014) yang berjudul Analisis Penatausahaan Dan Penyusunan Laporan Pertanggung jawaban Bendahara Serta Penyampaiannya Pada Dinas Pendapatan Pengelola Keuangan Dan Aset Daerah Kabupaten Bone Bolango, Tujuan 
penelitian untuk mengetahui kesesuaian pembukuan dan laporan pertanggungjawaban dengan peraturan yang berlaku. Metode analisis yang digunakan adalah analisis deskriptif. Hasil penelitian menunjukkan Dinas Pendapatan Pengelolaan Keuangan dan Aset Daerah (DPPKAD) Kabupaten Bone. Hasil penelitian dan pembahasan maka dapat diambil kesimpulan bahwa: Dinas Pendapatan Pengelolaan Keuangan dan Aset Daerah Kabupaten Bone Bolango selaku SKPKD telah melaksanakan penatausahaan dan penyusunan laporan pertanggungjawaban bendahara serta Penyampaiannya sesuai dengan peraturan yang berlaku. Hasil perbandingan Pada penelitian ini, merancang sistem informasi laporan pertanggung jawaban ini, hanya mengarah pada bagaimana membuat laporan pengeluaran bendahara dengan menggunakan pembukuan biasa sedangkan pada penelitian ini di fokuskan pada suatu sistem informasi yang mempermudah bendara dalam melakukan rekapan pengeluaran belanja serta gaji.

Berdasarkan kedua uraian peniltian diatas maka perbandingan dengan peniltian ini menggunakan bahasa pemrograman Visual Studio dan Ms. access sebagai databasenya sedangkan penelitian ini menggunakan metode pendekatan analisis top down dan model watefall.

\section{LANDASAN TEORI}

\section{Pengertian Sistem}

Sistem Informasi adalah gabungan terorganisasi yang terdiri dari manusia, perangkat lunak, perangkat keras, jaringan komunikasi dan sumber data dalam mengumpulkan, mengubah, dan menyebarkan informasi dalam suatu organisasi.

Berdasarkan defenisi tersebut maka dapat disimpulkan, sistem merupakan kumpulan dari beberapa himpunan elemen- elemen yang saling berinteraksi, memiliki keterkaitan dan saling bekerja sama serta membentuk suatu kesatuan untuk mencapai suatu tujuan atau sasaran tertentu.

\section{Karakteristik Sistem}

Jogiyanto (2014) mengatakan bahwa suatu sistem mempunyai karakterisktik atau sifat-sifat tertentu, yaitu mempunyai komponen-komponen (components), batasan sistem (boundary), lingkungan luar sistem (environments), penghubung (interface), masukan (input), keluaran (output), pengolah (process), dan sasaran (objectives).

\section{Pengertian Laporan}

Soegito dalam Wardani (2008), laporan berisi informasi yang didukung oleh data yang lengkap sesuai dengan fakta yang ditemukan. Data disusun sedemikian rupa sehingga akurasi informasi yang kita berikan dapa dipercaya dan mudah dipahami.

\section{Pengertian Realisasi}

Menurut Mardiasmo

(2009:21)

realisasi adalah "Proses menjadikan nyata, perwujudan, pelaksanaan yang nyata." Nordiawan (2010:115) Realisasi adalah "Proses yang harus diwujdkan untuk menjadi kenyataan dan pelaksanaan yang nyata agar realisasi dapat sesuai dengan harapan diinginkan.”

\section{Pengertian Anggaran}

Nafarin (2012:15) anggaran adalah "Suatu rencana tertulis mengenai kegiatan suatu organisasi yang dinyatakan secara kualitatif dan umumnya dinyatakan dalam satuan uang atau dalam jangka waktu tertentu."

\section{Bendahara Pengeluaran}

Menurut BDK Balikpapan Bendahara Pengeluaran adalah salah satu Pejabat Perbendaharaan Negara yang mempunyai 
tugas diantaranya melakukan pembayaran atas uang yang ada dalam kewenangannya. Bendahara Pengeluaran sebelum melakukan pembayaran harus melakukan pengujian kelengkapan persyaratan, menguji ketersediaan dana, dan menguji kebenaran perhitungan tagihan. Apabila terjadi kesalahan pembayaran baik sengaja maupun lalai yang mengakibatkan kerugian bagi negara maka bendahara dapat dikenakan sanksi hukum administrasi maupun sanksi hukum pidana

\section{Pengertian Akuntansi}

Danang (2013: 18), “Akuntansi adalah proses pencatatan, penggolongan, peringkasan,, pelaporan, dan penganalisisan data keuangan suatu organisasi”

\section{Pengertian DFD (Data flow Diagram)}

Sutabri (2012) Data Flow Diagram adalah suatu network yang menggambarkan suatu system automa atau komputerisasi, manualisasi, atau gabungan dari keduanya, yang penggambaranya disusun dalam bentuk kumpulan komponen sitem yang saling berhubungan sesuai aturan mainnya.

Keuntungan penggunaan DFD adalah memungkinkan untuk menggambarkan sistem dari level yang paling tinggi kemudian menguraikannya menjadi level yang lebih rendah (dekomposisi). Sedangkan kekurangan penggunaan DFD adalah tidak menunjukkan proses pengulangan (looping), proses keputusan dan proses perhitungan.

\section{ERD (Entity Relationship Diagram)}

Menurut Brady M. Loonam J (2010), dalam bahasa indonesia bahwa Entity Relationship diagram (ERD) merupakan teknik yang digunakan untuk memodelkan kebutuhan data dari suatu organisasi, biasanya oleh System Analys dalam tahap analisis persyaratan proyek pengembangan system. Sementara seolah-olah teknik diagram atau alat peraga memberikan dasar untuk desain database relasional

\section{Pengertian Basis Data (Database)}

Menurut Ladjmudin (2013:129),

"Database adalah sekumpulan data store (bisa dalam jumlah yang sangat besar) yang tersimpan dalam magnetic disk, optical disk, magnetic drum atau media penyimpanan sekunder lainnya".

\section{Pengertian Visual Studio}

Microsoft Visual Studio by merupakan sebuah perangkat lunak lengkap (suite) yang dapat digunakan untuk melakukan pengembangan aplikasi, baik itu aplikasi bisnis, aplikasi personal, ataupun komponen aplikasinya, dalam bentuk aplikasi console, aplikasi Windows, ataupun aplikasi Web. Visual Studio mencakup kompiler, SDK, Integrated Development Environment (IDE), dan dokumentasi (umumnya berupa MSDN Library). Kompiler yang dimasukkan ke dalam paket Visual Studio antara lain Visual $\mathrm{C}++$, Visual C\#, Visual Basic, Visual Basic .NET, Visual InterDev, Visual J++, Visual J\#, Visual FoxPro, dan Visual SourceSafe.

\section{Pengertian Microsoft Accsess}

Menurut Ahmad Iskandar (2003) dalam modulnya yang berjudul Microsoft Access adalah Microsof Access adalah salah satu software database yang berjalan dibawah sistem windows, dengan Microsoft Access kita dapat merancang, memuat dan mengelola database dengan cara mudah dan cepat.

\section{Pengertian Crystal Report}

Irnawan dan Yesni (2011). Crystal Report juga merupakan aplikasi khusus yang digunakan untuk merancang berbagai macam jenis laporan. Pertama kali Crystal Report diciptakan oleh Crystal Services Inc sebagai alat bantu untuk mereka untuk menciptakan Report secara mudah dan cepat. 


\section{MATODE PENELITIAN}

\section{Lokasi dan Waktu Penilitian}

Peneliti memilih objek penelitian yang bertempat di Kantor Camat Oba Selatan. Sedangkan waktu penelitian ini berlangsung selama dua bulan yaitu sejak bulan mei sampai dengan bulan juli 2018

\section{Metode Pengumpulan Data}

Metode pengumpulan data yang digunakan dalam penelitian ini adalah dokumentasi dan wawancara.

\section{Dokumentasi}

Dokumentasi menurut Sugiyono (2015: 329) adalah suatu cara yang digunakan untuk memperoleh data dan informasi dalam bentuk buku, arsip, dokumen, tulisan angka dan gambar yang berupa laporan serta keterangan yang dapat mendukung penelitian. Dokumentasi digunakan untuk mengumpulkan data kemudian ditelaah

\section{Wawancara}

Teknik wawancara dalam penelitian ini menggunakan teknik wawancara bebas terpimpin. Arikunto (2013: 199) menjelaskan bahwa wawancara bebas terpimpin adalah wawancara yang dilakukan dengan mengajukan pertanyaan secara bebas namun masih tetap berada pada pedoman wawancara yang sudah dibuat.

\section{Studi Kepustakaan}

Dengan mencari dan mengumpulkan data yang diperlukan dari berbagai bukubuku, catatan-catatan, dan gambar-gambar yang menunjang penyusunan laporan tugas akhir ini.

\section{Alur Penelitian}

Dalam melakukan penelitian tentunya memiliki alur atau kerangka penelitiann yang mana. Alur penelitian tersebut dapat memudahkan peneliti dalam melakukan penelitian. Adapun kerangka penelitian ini adalah sebagai berikut:

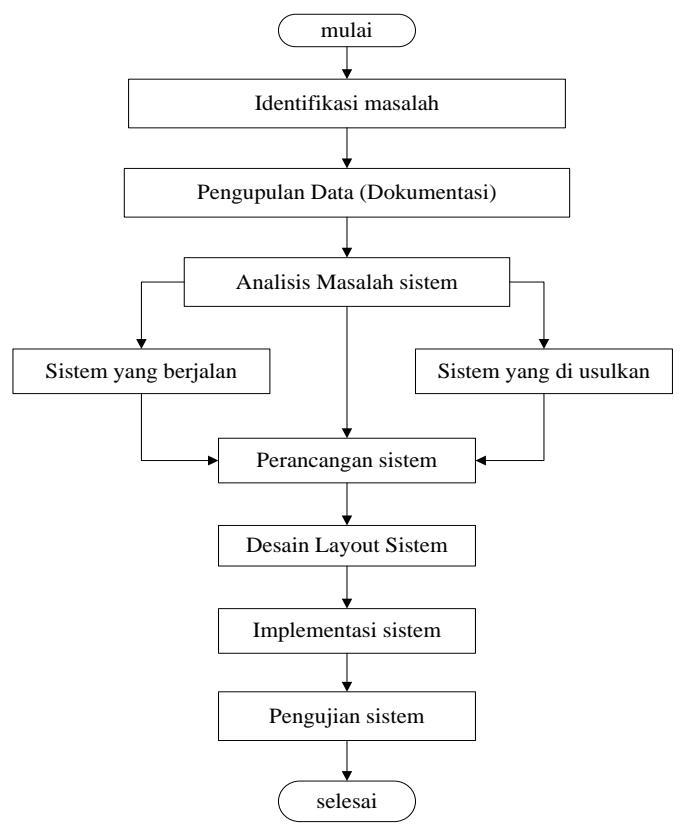

Gambar 1. Alur Penelitian

\section{ANALISIS DAN PERANCANGAN}

Sistem yang berjalan pada Kecamatan Oba Selatan, masih bersifat konvensional. Dimana data-data belanja dan pengeluaran Kas masih dicatat secara manual didalam buku seperti uang persediaan (UP), ganti uang (GU), tambahan uang (TU) dan lainlain. Sehingga di butuhkan suatu sistem yang mempermudah admin dalam proses penginputan data belanja, pengeluaran Kas dan seterusnya.

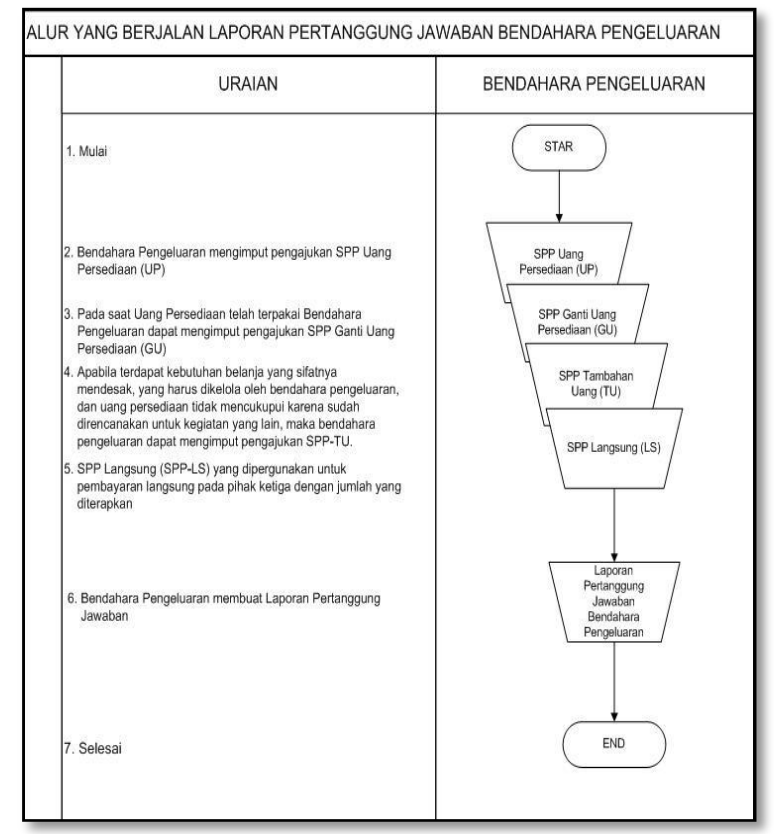


Gambar 2. Flowchart Sistem yang berjalan

\section{Analisis Sistem Yang Diusulkan}

Berdasarkan masalah yang ada pada sistem yang berjalan maka diusulkan sistem yang baru untuk dapat mempermudah admin atau bendahara dalam mengelola Penghitungan laporan pengeluaran belanja oleh bendahara pengeluaran. berikut merupakan rancangan usulan sistem Penyusunan Laporan Pertanggungjawaban Bendahara Pengeluaran yang diusulkan dapat ditampilkan pada gambar flowchart sebagai berikut:

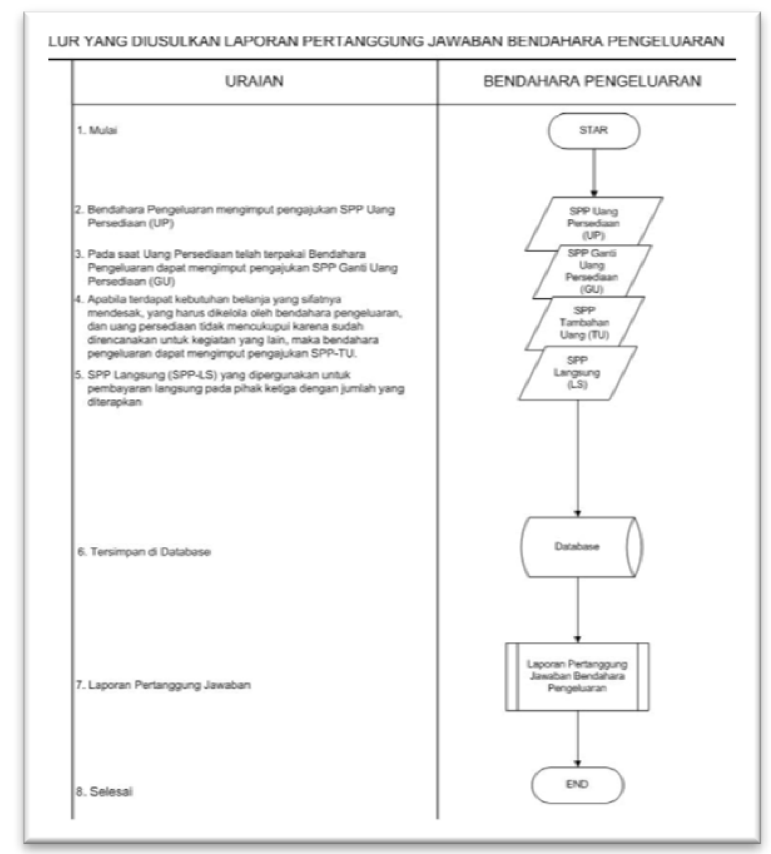

Gambar 3. Sistem yang diusulkan

\section{Perangkat Keras}

Perangkat keras yang digunakan dalam penelitian ini berupa perangkat keras(hardware) dengan spesifikasi yaitu:

1. Laptop Axioo-PC

2. Procesor Intel(R) Atom ${ }^{\mathrm{TM}}$ CPU N570 @1.666GHz

3. Ram 2,00 GB

4. Hardisk $160 \mathrm{~GB}$

5. Printer Canon ip2870S

\section{Perangkat Lunak}

Alat yang digunanakan dalam penelitan ini berupa perangkat lunak (software).
1. Windows7 Ultimate sebagai system operasi

2. Ms. Access 2007 sebagai pengelola database

3. Bahasa Programan Visual Studio

4. Microsoft Visio 2007

\section{Diagram Konteks}

Diagram konteks adalah diagram yang menggambarkan hubungan antara entitas eksternal dengan sistem. Dimana data yang diinputkan oleh bagian entitas eksternal akan diproses di dalam sistem dan akan menghasilkan laporan yang diinginkan oleh eksternal tersebut. Untuk lebih jelasnya dapat dilihat pada gambar berikut ini :

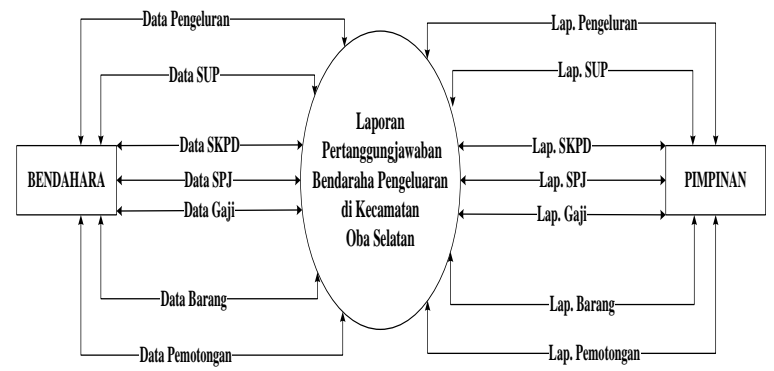

Gambar 4. Diagram Conteks

\section{Diagram Flow Data (DFD Level 1)}

Data flow diagram atau yang disingkat DFD merupakan suatu diagram yang menggunakan alir data dalam suatu entitas ke sistem atau sistem ke entitas, atau bisa dikatakan sebagai diagram yang menggunakan notasi simbol untuk menggambarkan data sistem yakni kesatuan luar (External entity), arus data (Data flow), proses (Process), dan simpanan data (Data store). 


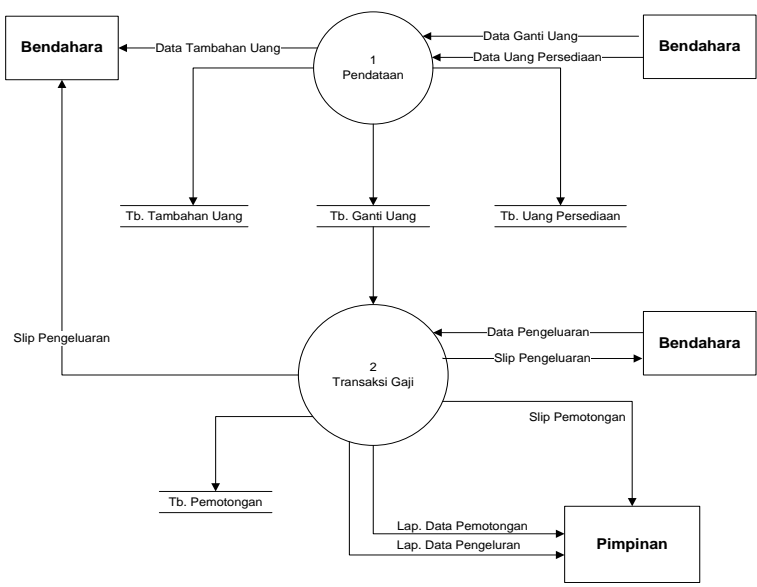

Gambar 5. Diagram Flow Data Level 1

\section{Entity Relationship Diagram (ERD) Notasi}

Entity Relationship Diagram (ERD) digunakan untuk menggambarkan hubungan yang terjadi pada setiap entitas pengeluaran pada Laporan Pertanggungjawaban Bendahara Pengeluaran di Kecamatan Oba Selatan ialah sebagai berikut :

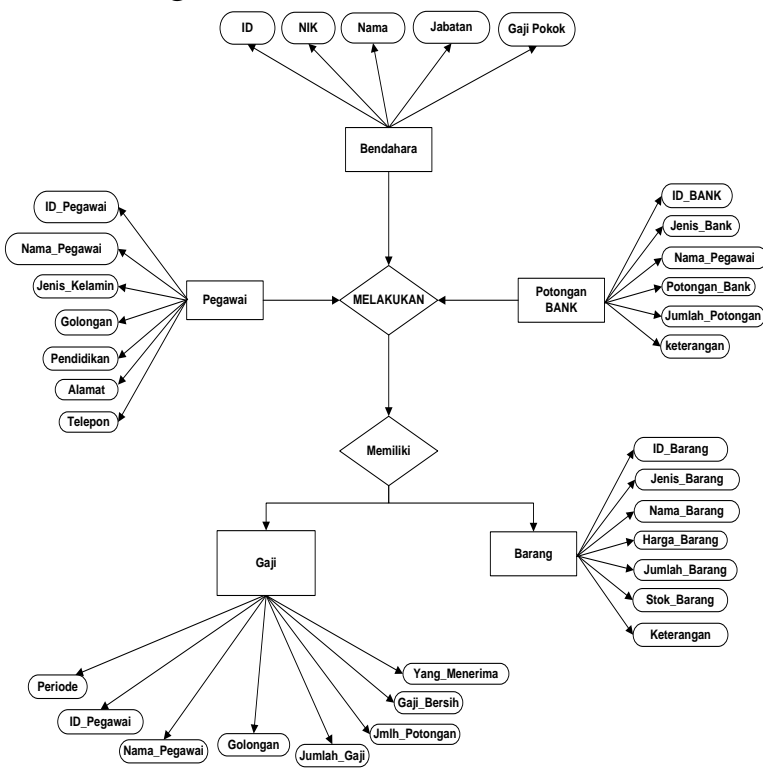

Gambar 6. Entity Relationship Diagram

\section{Perancangan Database dan Tabel}

Perancangan basis data merupakan langkah untuk menentukan basis data yang diharapkan dapat mewakili seluruh kebutuhan pengguna.

1. Entitas, merupakan objek atau kejadian yang mewakili sesuatu yang nyata. Pada model relational, entitas akan menjadi table.

2. Atribut, adalah item data yang menjadi bagian dari suatu entitas atau yang mendeskripsikan karakteristik dari entitas.

3. Record, adalah kumpulan elemenelemen yang saling berkaitan menginformasikan suatu entitas secara lengkap. Misalnya informasi nama, alamat dll.

4. Data value (nilai atau isi data), adalah data aktual atau informasi yang disimpan pada tiap data elemen atau atribut.

5. File, adalah kompulan record - record sejenis yang mempunyai panjang elemen yang sama.

6. Hubungan, adalah kaitan dengan duat entitas.

7. Kunci Primer (primary key), adalah kunci kadidat ang dipilih sebagai kunci utama untuk mengidentifikasikan barisan dalam table. Kunci Tamu ( Foreign Key ), adalah sebarangan atribut yang menunjuk ke kunci primer pada tabel lain.

\section{Tabel Pengguna}

Tabel pengguna digunakan untuk menyimpan data yang berhubungan dengan Id pengguna . Spesifikasi dari tabel pengguna adalah sebagai berikut :

Tabel 1. Tabel Pengguna

\begin{tabular}{|l|l|l|l|}
\hline Field Name & $\begin{array}{l}\text { Data } \\
\text { Type }\end{array}$ & Size & Primary Key \\
\hline Kd_Pengguna & Text & 12 & Yes \\
Nm_Lengkap & Text & 40 & No \\
User_Name & Text & 25 & No \\
Pass & Text & 12 & No \\
& & & \\
\hline
\end{tabular}

\section{Tabel Skin}

Tabel Skin digunakan untuk menyimpan data yang berhubungan dengan pangkat atau jabatan pada pegawai. Spesifikasi dari tabel kategori adalah sebagai berikut : 
Tabel 2. Tabel Skin

\begin{tabular}{|l|l|l|l|}
\hline Field Name & Data Type & Size & Primary Key \\
\hline Kode_Skin & Text & 12 & Yes \\
Skin & Text & 50 & No \\
\hline
\end{tabular}

\section{Tabel Gaji}

Tabel Gaji digunakan untuk menyimpan data yang berhubungan dengan gaji pegawai. Spesifikasi dari tabel pegawai adalah sebagai berikut :

Tabel 3. Tabel Gaji

\begin{tabular}{|l|l|l|l|}
\hline Field Name & Data Type & Size & $\begin{array}{l}\text { Primary } \\
\text { Key }\end{array}$ \\
\hline Kode_SP & Text & 12 & Yes \\
Julan_Lalu & Number & - & No \\
Bulan_Ini & Number & - & No \\
sd_Bulan_Ini & Number & - & No \\
Tahun_Anggaran & Date/Time & - & No \\
Bulan & Date/Time & - & No \\
\hline
\end{tabular}

\section{Tabel Barang Jasa}

Tabel Barang Jasa digunakan untuk menyimpan data yang berhubungan dengan Barang. Spesifikasi dari tabel barang jasa adalah sebagai berikut :

Tabel 4. Tabel Barang jasa

\begin{tabular}{|l|l|l|l|}
\hline Field Name & Data Type & Size & $\begin{array}{l}\text { Primary } \\
\text { Key }\end{array}$ \\
\hline Kode_SPJ & Text & 12 & Yes \\
Bulan_Lalu & Number & - & No \\
Bulan_Ini & Number & - & No \\
sd_Bulan_Ini & Number & - & No \\
Tahun_Anggaran & Date/Time & - & No \\
Bulan & Date/Time & - & \\
\hline
\end{tabular}

\section{Tabel SUP}

Tabel SUP digunakan untuk menyimpan data yang berhubungan dengan karyawan. Spesifikasi dari tabel pendapatan pegawai adalah sebagai berikut :

Tabel 5. Tabel SUP

\begin{tabular}{|l|l|l|l|}
\hline Field Name & Data Type & Size & $\begin{array}{l}\text { Primary } \\
\text { Key }\end{array}$ \\
\hline Kode_SPJ & Text & 12 & Yes \\
Bulan_Lalu & Number & - & No \\
Bulan_Ini & Number & - & No \\
sd_Bulan_Ini & Number & - & No \\
Tahun_Anggaran & Date/Time & - & No \\
\hline
\end{tabular}

Bulan Date/Time

\section{Tabel SKPD}

Tabel SKPD digunakan untuk menyimpan data yang berhubungan dengan instansi. Spesifikasi dari tabel SKPD adalah sebagai berikut :

Tabel 6. Tabel SKPD

\begin{tabular}{|l|l|l|l|}
\hline Field Name & $\begin{array}{l}\text { Data } \\
\text { Type }\end{array}$ & Size & $\begin{array}{l}\text { Primary } \\
\text { Key }\end{array}$ \\
\hline Kode_SKPD & Text & 12 & Yes \\
Nama_SKPD & Text & 20 & No \\
Kabupaten & Text & 25 & No \\
Pengguna_Anggaran & Text & 15 & No \\
Bendahara_Pengeluaran & Text & 25 & \\
\hline
\end{tabular}

\section{Tabel SPJ}

Tabel SPJ digunakan untuk menyimpan data yang berhubungan dengan surat pertanggungjawaban. Spesifikasi dari tabel SPJ adalah sebagai berikut :

Tabel 7. Tabel SPJ

\begin{tabular}{|l|l|l|l|}
\hline Field Name & $\begin{array}{l}\text { Data } \\
\text { Type }\end{array}$ & Size & $\begin{array}{l}\text { Primary } \\
\text { Key }\end{array}$ \\
\hline Kode_SPJ & Text & 12 & Yes \\
Tahun_Anggaran & Date/Time & - & No \\
Bulan & Date/Time & - & No \\
Kode_SKPD & Text & 12 & No \\
Kode_Rekening & Text & 14 & No \\
Uraian & Text & 50 & No \\
Jumlah_Anggaran & Number & - & No \\
Jumlah_SPJ & Number & - & \\
Sisa_Pagu_Anggaran & Number & - & \\
\hline
\end{tabular}

\section{Relation Table}

Hubungan antar tabel (Relation) adalah hubungan antara sebuah tabel dengan beberapa tabel yang lainnya. Hubungan ini menunjukkan relasi antara tabel sehingga membentuk suatu jaringan data. Pada sistem informasi Laporan Pertanggungjawaban Bendahara Pengeluaran dengan relasi antar tabelnya adalah sebagai berikut : 


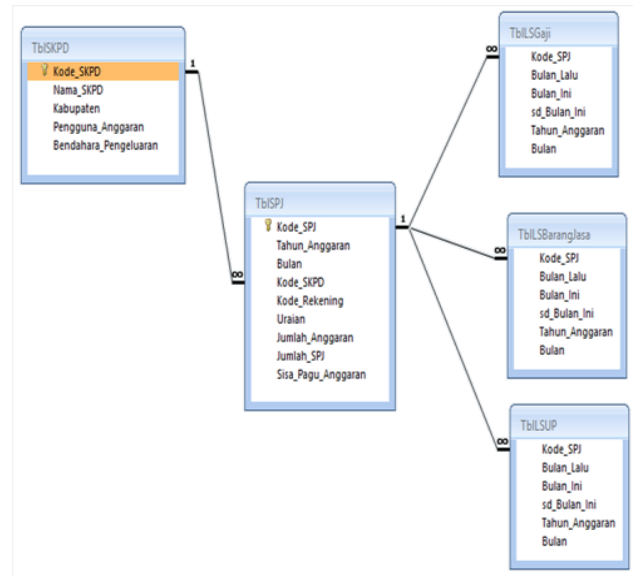

Gambar 7. Relasi Antar Tabel

\section{IMPLEMENTASI DAN PEMBAHASAN}

$\begin{array}{ccr}\text { Implementasi } & \text { sistem } & \text { (system } \\ \text { implementation) } & \text { adalah } & \text { tahap } \\ \text { meletakkan sistem } & \text { supaya } & \text { siap }\end{array}$
dioperasikan. Kegiatan implementasi dilakukan dengan dasar kegiatan yang telah direncanakan dalam kegiatan implementasi antara lain :pemilihan dan pelatihan personil, instalasi hardware dan software, pengetesan program, pengetesan sistem dan konversi sistem.

\section{Implementasi Sistem}

Sistem informasi kartu hasil studi (KHS) merupakan sistem yang digunakan untuk mengolah data nilai mahasiswa. Tujuan pembuatan sistem ini adalah sebagai alat agar memudahkan untuk mengolah data nilai mahasiswa. Sistem ini diimplementasikan pada perangkat komputer yang terinstal web server dan web browser sehingga dapat terhubung dengan jaringan lokal.

\section{Sistem indormasi Laporan}

Pertanggungjawaban

Bendahara

Pengeluaran di Kecamatan Oba Selatan. Tujuan pembuatan sistem ini adalah sebagai alat untuk mempermudah pengeluaran anggaran di Kantor Camat Oba Selatan. Sistem ini diimplementasikan pada perangkat komputer yang terinstal tanpa menggunakan aplikasi terseubut tapi dijalankan menggunakan file setup dengan menampilkan data-data SKPD, penggajian, pemotongan, barang dan jasa serta laporan SKPD, gaji pegawai serta slip gaji pada masing-masing pegawai.

\section{Form Login Administrator}

Pada gambar di bawah ini merupakan halaman tampilan form login admin. Orang yang berhak melakukan akses pada halaman ini harus login terlebih dahulu dengan memasukan username dan password. Penguna yang berhak melakukan proses login ini adalah administrator.

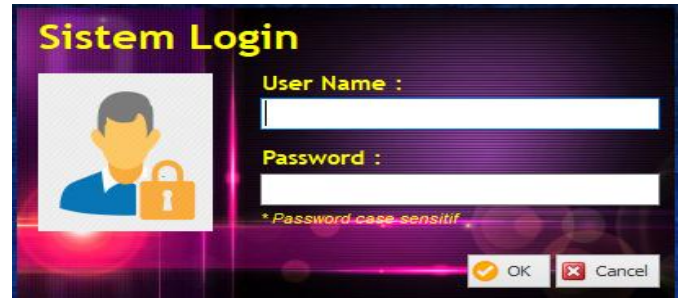

Gambar 8. Gambar Form Login

\section{Form Ubah Password}

Pada gambar di bawah ini merupakan halaman tampilan form ubah password. Orang yang berhak melakukan proses perubahan data pada halaman login terlebih dahulu dengan memasukan username dan password yang lama dan menggantikan dengan username dan password.

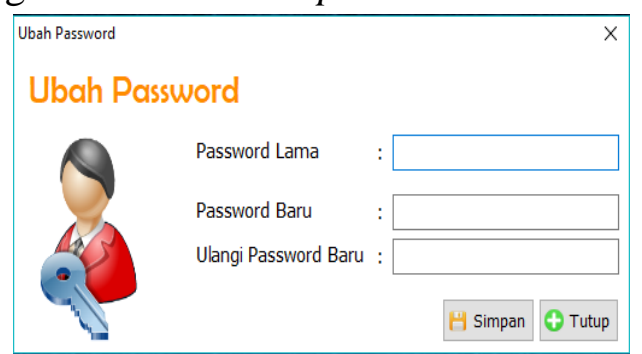

Gambar 9. Gambar Form Ubah Password

\section{Form Data Pengguna}

Pada gambar di bawah ini merupakan halaman tampilan form data pengguna digunakan untuk menyimpan data yang berhubungan dengan admin. Spesifikasi dari form data pengguna adalah sebagai berikut : 


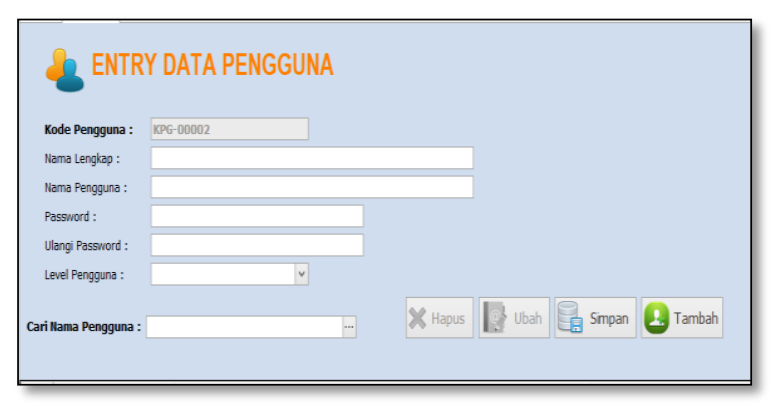

Gambar 10. Gambar Form Data Pengguna

\section{Form Data SKPD}

Pada gambar di bawah ini merupakan tampilan form untuk menginput data SKPD dan di simpan ke database yang nantinya di tampilkan pada tabel dan laporan data SKPD setelah mengclick tombol simpan. Serta masukkan kata kunci untuk menampilkan salah satu bentuk data yang akan di cari maka nantinya bisa di ubah dan hapus data .

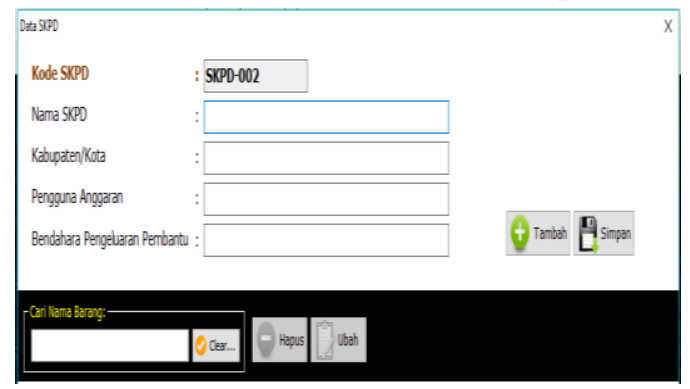

Gambar 11. Form Data SKPD

\section{Form Data SPJ - LS Gaji}

Pada gambar di bawah ini merupakan tampilan form untuk menginput data SPJ LS Gaji dan di simpan ke database yang nantinya di tampilkan pada tabel dan laporan data SPJ - LS Gaji setelah mengclick tombol simpan. Serta masukkan kata kunci untuk menampilkan salah satu bentuk data yang akan di cari maka nantinya bisa di ubah dan hapus data .

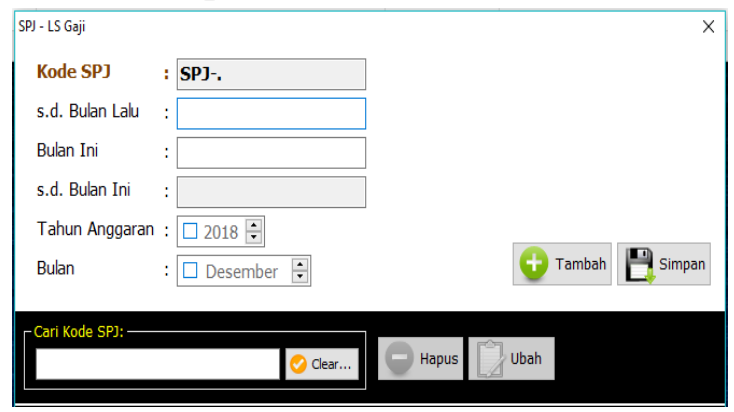

Gambar 12. Form Data SPJ - LS Gaji

\section{Form Data SPJ - LS Barang \& Jasa}

Pada gambar di bawah ini merupakan tampilan form untuk menginput data SPJ LS Barang \& Jasa dan di simpan ke database yang nantinya di tampilkan pada tabel dan laporan data SPJ - LS Barang \& Jasa setelah mengclick tombol simpan. Serta masukkan kata kunci untuk menampilkan salah satu bentuk data yang akan di cari maka nantinya bisa di ubah dan hapus data .

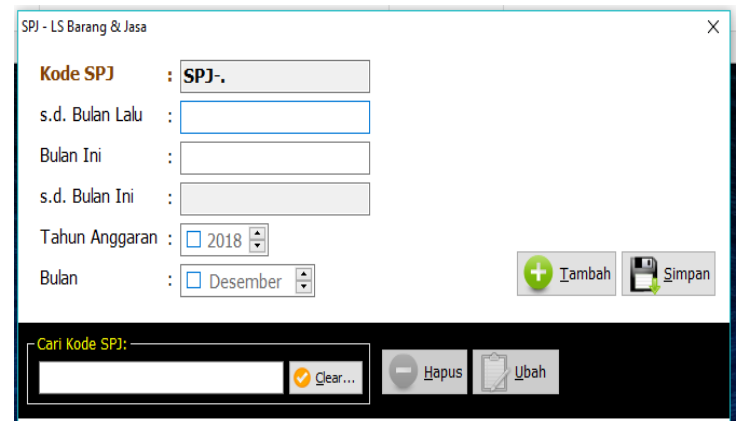

Gambar 13. Form Data SPJ - LS

\section{Form Data SPJ - UP/GU/TU}

Pada gambar di bawah ini merupakan tampilan form untuk menginput data SPJ UP/GU/TU dan di simpan ke database yang nantinya di tampilkan pada tabel dan laporan data SPJ - UP/GU/TU setelah mengklik tombol simpan. Serta masukkan kata kunci untuk menampilkan salah satu bentuk data yang akan di cari maka nantinya bisa di ubah dan hapus data

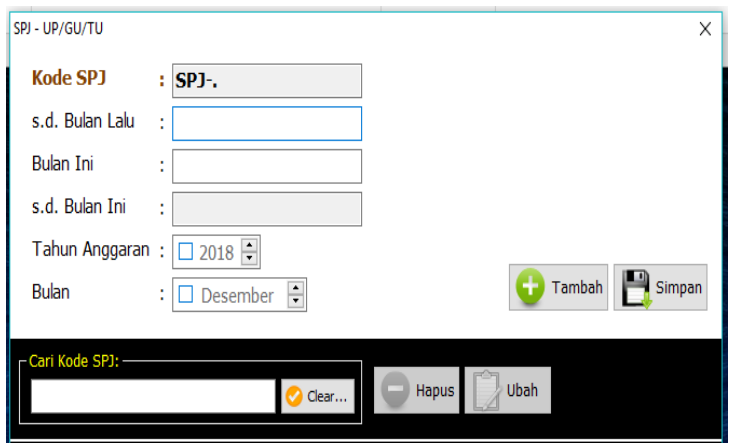

Gambar 14. Form Data SPJ - UP/GU/TU

\section{Form Data SPJ}

Pada gambar di bawah ini merupakan tampilan form laporan seluruh pengeluaran bendahara baik pemotongan belanja barang dan jasa, gaji pegawai. Serta masukkan kata kunci untuk menampilkan salah satu bentuk 
data yang akan di cari maka nantinya bisa di ubah dan hapus data.

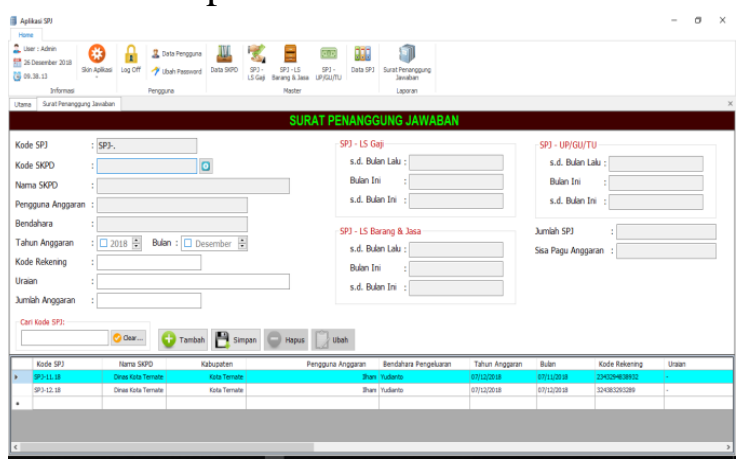

Gambar 15. Form Data SPJ

\section{Form Laporan Surat Penanggung Jawaban}

Pada gambar di bawah ini merupakan tampilan form laporan penanggung jawaban secara keseluruh. Dalam form tersebut dapat dilakukan operasi data dengan melihat data pengeluaran belanja barang dan jasa serta gaji pegawai, klik tombol cetak untuk mencetak data pengeluaran dan export data pengeluaran dalam bentuk file pdf dan lainlain

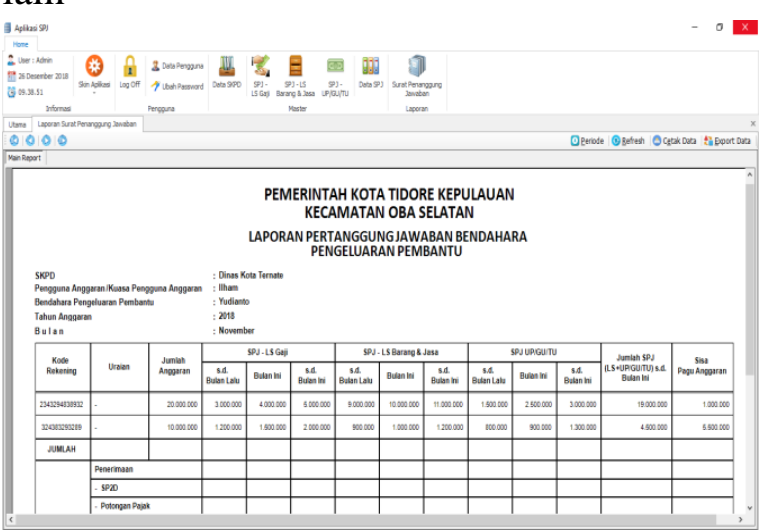

Gambar 16. Laporan Hasil

\section{Kesimpulan}

a. Memberi kemudahan dalam memasukan data belajan barang, mengolah data gaji pegawai, serta pembuatan laporan pengeluaran bendahara pengeluaran berdasarkan periode.

b. Dengan adanya sistem baru ini diharapkan dapat membantu dalam perhitungan data belanja barang serta gaji pegawai agar lebih cepat, tepat dan mudah.
Kelebihan dari sistem ini adalah:

a. Dalam pencarian data lebih cepat.

b. Dapat meminimalkan kesalahan dalam memasukan data, proses perhitungan belanja barang serta meminimalkan kesalahan yang terjadi.

c. Bentuk menu data telah dibuat user friendly, sehingga dalam memasukan data memberikan kemudahan.

\section{Saran}

a. Sebelum sistem baru dilaksanakan, sebaiknya seluruh personil yang terkait dalam sistem harus diberikan penjelasan dengan baik terlebih dahulu mengenai proses kerja sistem yang akan di terapkan sehingga tidak terjadi kekeliruan. Serta perlu dilakukan pelatihan kerja terhadap personil yang terlibat dalam sistem ini agar mereka dapat mengetahui dan memahami cara kerja sistem yang baru.

b. Sistem Informasi pengeluaran ini menggunakan visual studio yang sederhana ini, diharapkan dapat di kembangkan lagi menggunakan client server yang lebih sempurna.

c. Sistem informasi yang baru ini hanya mampu dalam pengolahan data belanja barang, gaji pegawai, dan proses perhitungan pengeluaran secara keseluruhan. Diharapkan akan ada pengembangan lagi mengenai sistem ini agar lebih banyak menghasilkan informasi yang diinginkan.

\section{DAFTAR PUSTAKA}

Ahmad Iskandar (2003) dalam modulnya "Microsoft Access"

Arikunto, S. (2013). Prosedur Penelitian: Suatu Pendekatan Praktik. Jakarta: Rineka Cipta.

Al-Bahra Bin Ladjamudin. 2013. Analisis dan Desain Sistem Informasi. Graha Ilmu. Yogyakarta 
Brady M. Loonam J. 2010. Exploring the use of entity-relationship diagramming as a technique to support grounded theory inquiry. Qualitative Research in Organization And Management

Danang (2013), analisis penatausahaan dan penyusunan laporan pertanggung jawaban bendahara. Jurnal Berkala Ilmiah Efisiensi, Volume 16 No. 04 Tahun 2016

Darman Umagapi, Syahril Hasan. Sistem Informasi Pengendalian Internal Prosedur Pencatatan Akuntansi Penggajian Pada PT. Halmahera Karya Timur Persada Menggunakan Visual Studio. (IJIS) Volume 3 Nomor 2 Bulan September 2018, e-ISSN 2548-6438, p-ISSN 2614-7173

Halim, Abdul dan Kusufi, M.S. (2013). Akuntansi Sektor Publik: Akuntansi Keuangan Daerah (Ed. ke-4). Jakarta: Salemba Empat.

Irnawan, Yesni Malau. (2011). Apapun Permintaannya Crystal Report Jawabannya!. Jakarta : PT Elex Media Komputindo.

Jogiyanto. (2014). Analisis dan Desain Sistem Informasi, Sistem Informasi: Pendekatan Terstruktur Teori dan Praktik Aplikasi Bisnis. Yogyakarta: Andi Offset.

Mardiasmo. (2009), Akuntansi sektor Publik, CV Andi OFFSET, Yogyakarta.

Wikipedia Bahasa Indonesia Ensiklopedia Bebas, Microsoft Visual Studio, di akses $27 \quad$ Juli 2019, https://id.wikipedia.org/wiki/Microsoft _Visual_Studio

Nafarin, M. (2012). Penganggaran Rencana Kerja perusahaan. Edisi Kesatu. Jakarta: Salemba Empat.

Nordiawan, Dedi. (2010), Akuntansi Sektor Publik, Salemba Empat, Jakarta. Pemerintah Daerah Berbasis Akrual. Yogyakarta: UPP STIM YKPN

Republik Indonesia, Komite SAP. PSAP Nomor 2 tentang Laporan Realisasi Anggaran.

Republik indonesia, Peraturan Pemerintah Nomor 71 Tahun 2010 Tentang
Standar Akuntansi Pemerintahan (SAP).

Republik Indonesia, Undang-Undang Nomor 1 Tahun 2004 tentang Perbendaharaan Negara , Undang-Undang Nomor 17 tahun 2003 tentang Keuangan Negara. , Undang-Undang Nomor 23 Tahun 2014 Tentang Pemerintah Daerah.

, Undang Undang Nomor 32 Tahun 2004 tentang Pemerintahan Daerah.

Sugiyono, (2013). Metode Penelitian Kuatitatif, Kualitatif dan $R \& D$. (Bandung: ALFABETA)

Sugiyono (2015). Metode Penelitian Kombinasi (Mix Methods). Bandung: Alfabeta.

Wardhani, IGK,2008, Penelitian Tindakan Kelas. Jakarta: Universitas Terbuka

Sutabri, T. ( 2012). Analisis Sistem Informasi. Andi. Yogyakarta

Yakub, (2012). Pengantar Sistem Informasi. Graha Ilmu. Yogyakarta.

Elsya Vera Indraswari, Noor Latifah, Sistem Informasi Surat Pertanggung Jawaban (SPJ) Pembantu Bendahara Pengeluaran Pada Badan Kepegawaian Daerah Kudus, Prosiding SNATIF Ke -1 Tahun 2014, ISBN: 978-602-1180-04-4

Rizky Rahmatiah, Analisis Penatausahaan Dan Penyusunan Laporan Pertanggung jawaban Bendahara Serta Penyampaiannya Pada Dinas Pendapatan Pengelola Keuangan Dan Aset Daerah Kabupaten Bone Bolango, JURNAL EMBA: JURNAL RISET EKONOMI, MANAJEMEN, BISNIS DAN AKUNTANSI, Vol 4, No 1 Tahun 2016, ISSN 2303-1174

BDK Balikpapan, Kedudukan dan Tanggung Jawab Bendahara Pengeluaran dalam Perspektif Hukum, di akses Tanggal 27 Bulan Juli Tahun 2019,

https://bppk.kemenkeu.go.id/id/publika si/artikel/147-artikel-anggaran-danperbendaharaan/25715-kedudukandan-tanggung-jawab-bendaharapengeluaran-dalam-perspektif-hukum 